\title{
BENTUK DAN MAKNA RESIPROSITAS \\ DALAM TRADISI NGAMEK ARI MASYARAKAT BANYUASIN III \\ The Form and Meaning Reciprosity in Ngamek Ari Tradition Banyuasin III Society
}

\author{
Imron Hadi \\ Balai Bahasa Sumatera Barat \\ Simpang Alai, Cupak Tangah, Pauh, Padang 25162 \\ Telepon (0751) 776789, Faksimile (0751)776788 \\ Telepon: 08126765784; Pos-el: imron.hadi@kemdikbud.go.id \\ (Diterima: 16 Mei 2019, Disetujui: 26 September 2019)
}

\begin{abstract}
The advancement of science and technology has scratched out the form and meaning in the tradition of Ngamek Ari as a reciprocity that lives in the society of Banyuasin regency, especially in Petaling village. Therefore, this article examines the form and meaning of reciprocity in Ngamek Ari tradition through data required from the perpetrators of reciprocity. The method used is descriptive qualititave method by recording and taking notes with active participant technique. The results show that there are three forms of Ngamek Ari: Ngamek Ari with energy, Ngamek Ari with materials or good, and Ngamek Ari with money (auction). The person who becomes the object to Ngamek Ari is obliged to return (mayar utang) more (ngiring) or equivalent as received. The conclusion is that Banyuasin III society, especially Petaling villagers do the tradition of Ngamek Ari aims to lighten the burden of the owner of the celebration or work.
\end{abstract}

Keywords: Ngamek Ari, reciprocity, tradition

\begin{abstract}
Abstrak
Kemajuan ilmu pengetahuan dan teknologi telah menggerus bentuk dan makna resiprositas dalam tradisi Ngamek Ari yang hidup di tengah masyarakat Banyuasin III, khususnya di Desa Petaling. Artikel ini mengkaji bentuk dan makna resiprositas dalam tradisi Ngamek Ari yang ada di tengah masyarakat melalui data yang bersumber dari pelaku resiprositas. Metode yang digunakan dalam kajian ini adalah deskriptif kualitatif dengan teknik rekam dan simak libat cakap. Hasil penelitian menunjukkan bahwa ada tiga bentuk Ngamek Ari, yaitu Ngamek Ari dengan tenaga, bahan atau barang, dan uang (lelang). Orang yang menjadi objek untuk Ngamek Ari wajib mengembalikan (mayar utang), lebih (ngiring), atau minimal setara dengan bantuan yang telah dia terima. Kesimpulannya bahwa masyarakat Banyuasin III, khususnya Desa Petaling melakukan tradisi Ngamek Ari bertujuan meringankan beban pemilik hajatan atau kerja.
\end{abstract}

Kata kunci: Ngamek Ari, resiprositas, tradisi 


\section{Pendahuluan}

Indonesia dikenal dunia karena salah satu sifat masyarakatnya yang tolong-menolong atau gotong royong sebagai sebuah tradisi. Tradisi itu masih ada dan dapat ditemui hingga sekarang terutama di desa-desa. Tradisi dilakukan dalam berbagai aspek kehidupan yang menguatkan ikatan silaturahmi anggota masyarakat, baik antarindividu maupun kelompok, serta bertujuan untuk membantu tanpa mengharapkan imbal-balik atau pamrih. Tradisi termasuk dalam bidang kehidupan manusia yang dapat dikatakan sebagai sesuatu yang penting. Contohnya pertalian atau hubungan keluarga, agama, pemerintahan, serta kultur kelas atas seperti seni dan sastra (Sobur, 2014).

Seiring perjalanan waktu dan tuntutan kehidupan, nilai luhur tolong-menolong mulai bergeser, memudar, dan luntur. Tradisi tersebut mulai berubah arah dari tindakan tanpa pamrih hingga berubah menjadi tindakan dengan pamrih.

Tradisi gotong royong dilakukan dengan tujuan menolong secara suka rela sebagai suatu nilai budaya, namun dewasa ini tindakan menolong dilakukan dengan mengharapkan akan ditolong kembali. Pertolongan atau bantuan yang diharapkan sekurang-kurangnya akan dibalas sebesar pertolongan atau bantuan yang pernah diberikan. Tindakan menolong atau membantu serupa itu yang mengharapkan ditolong kembali sebagai imbal balik dapat digolongkan sebagai resiprositas.

Secara sederhana, resiprositas adalah pertukaran timbal balik antarindividu, antarkelompok, atau antardesa. Block and Margaret (2014) memberi batasan resiprositas sebagai perpindahan barang atau jasa secara timbal balik dari kelompok-kelompok yang berhubungan secara simetris. Hubungan secara simetris adalah hubungan yang terbina karena hubungan darah, hubungan pertemanan, atau hubungan sosial yang terjalin baik di antara kedua belah pihak.

Resiprositas dalam kelompok masyarakat banyak ragamnya. Kegiatan tersebut dilakukan secara berkesinambungan, bersifat kolektif, dan melibatkan sejumlah orang sehingga menjadi kebiasaan atau tradisi. Resiprositas umumnya dengan mudah dapat ditemukan pada peristiwa hajatan (helat perkawinan, syukuran, aqiqah, dan sunatan), membuka ladang atau sawah baru, masa cocok taman, panen, membangun rumah, dan berbagai peristiwa lainnya.

Kebiasaan itu bagi masyarakat Banyuasin III dilaksanakan atau dilakukan dengan ragam motivasi dan tujuan yang tidak lepas dari pandangan hidup mereka, yaitu membantu (menolong) untuk meringankan beban pemilik hajatan atau gawean. Resiprositas tersebut dilakukan sebagai tindak kolektif masyarakat untuk memperlihatkan solidaritas dan partisipasi sebagai anggota keluarga atau masyarakat. Resiprositas dalam tindak tolong-menolong muncul dalam wujud sumbangan, seperti tenaga, uang, dan benda.

Seiring perjalanan waktu, pergeseran nilai dasar resiprositas, yaitu tolong-menolong di kalangan masyarakat mulai terjadi. Perubahan itu terdapat pada tujuan atau motivasi resiprositas yang diberikan. Jika sebelumnya resiprositas diberikan sebagai bentuk partisipasi, solidaritas, atau kesetiakawanan untuk meringankan pemilik hajatan, maka sekarang tujuan atau motivasi itu berubah, terutama yang berbentuk bantuan uang. Resiprositas berbentuk uang mengandung sebuah prestise pemberi bantuan karena semakin tinggi nilai bantuan yang diberikan semakin dipandang sebagai orang mampu atau berduit.

Dari penjelasan tersebut, tulisan ini memfokuskan kajian pada bentuk dan makna resiprositas dalam tradisi Ngamek Ari yang dilakukan masyarakat Banyuasin III. Berdasarkan observasi dan letak geografis, penentuan tempat pengambilan data adalah di Desa Petaling. Selain sebagai tempat perlintasan ke daerah lain, desa ini dikelilingi beberapa desa lain, seperti Terentang, Talangipuh, Galangtinggi, Sidangmas, Rimbaalai, dan Tanjung Beringin yang juga mengenal dan melakukan tradisi Ngamek Ari. 
Sebagai sebuah tradisi, Ngamek Ari juga dikenal dengan sambatan merupakan kegiatan yang dilakukan masyarakat secara kolektif sebagai bentuk ikatan sosial dalam bermasyarakat. Motivasi dan tujuan dari tradisi ini pada dasarnya untuk meringankan beban bagi yang mempunyai hajatan dalam bentuk bantuan yang dapat berwujud bahan makan, uang, dan bantuan tenaga. Berdasarkan wawancara diketahui bahwa tradisi ini telah ada sejak lama dan dilakukan turun-temurun dari generasi ke generasi dengan tujuan membantu orang yang akan dan sedang melaksanakan hajatan, seperti perkawinan, membuka lahan atau ladang, membajak sawah, membangun rumah, panen, dan lain sebagainya.

Kajian tentang resiprositas sudah dilakukan oleh beberapa penulis sebelumnya, seperti Stanca (2009) yang mengkaji cara mengukur resiprositas taklangsung dan menemukan bukti bahwa setiap perlakuan, baik strategi maupun keputusan memiliki dampak sebagai imbal balik. Resiprositas taklangsung umumnya ditemukan lebih kuat dan lebih menarik jika dibandingkan dengan resiprositas langsung. Temuan ini dipahami sebagai refleksi keterkaitan perilaku motivasi awal untuk resiprositas sesudahnya.

Engelmann dan Fischbacher (2009) melakukan kajian terhadap resiprositas taklangsung dan membangun raputasi strategi pada sebuah eksperimen bantuan pertandingan dan menemukan bahwa tidak hanya menjamin keberadaan resiprositas taklangsung, tetapi juga membantu bahwa substansi keputusan yang diambil dipengaruhi oleh pertimbangan strategi. Pendeknya, pemain yang punya strategi lebih baik daripda yang tidak memilikinya.

Pribadhi (2011) mengkaji resiprositas dalam kehidupan sosial ekonomi masyarakat. Kajian itu merupakan studi kasus di Kelurahan Kauman Kabupaten Blora bahwa bentuk resiprositas di daerah tersebut resiprositas sebanding dan umum. Sebanding artinya barang dan jasa yang dipertukarkan memiliki nilai sebanding dengan waktu pertukaran berlangsung (kapan memberikan, kapan menerima, dan kapan mengembalikan) dan umum berarti pertukaran barang atau jasa kepada individu atau kelompok lain tanpa menentukan batas waktu pengembalian.

Tujuan resiprositas adalah membantu masyarakat ketika ada salah satu warga yang melaksanakan pesta dan selamatan, yang menemukan atau mengalami hambatan seperti, keterbatasan anggaran, keterbatasan tenaga kerja, keterbatasan sarana dan prasarana. Resiprositas dilakukan untuk menutupi kekurangan atau keterbatasan dalam melaksanakan hajatan, sekaligus untuk menjaga silaturahmi antarwarga sehingga kerukunan dapat tercipta dengan baik. Sekelompok pemuda yang membantu hajatan juga dapat menjaga kesinambungan hubungan sosial di antara warga. Resiprositas dilihat dari sudut pandang ekonomi sebagai usaha untuk meringankan warga ketika mengadakan acara hajatan atau selamatan terutama masyarakat yang memiliki tingkat ekonomi menengah ke bawah.

Purnawan (2011) melakukan kajian tentang penerapan asas resiprositas dalam deklarasi persona non-grata bagi pejabat diplomatik bahwa asas resiprositas adalah asas yang fundamental dalam hukum diplomatik. Dalam kerangka hukum diplomatik, asas resiprositas diakui dan diterima sebagai asas hukum umum yang melandasi ketentuan yang ada dalam perjanjian internasional dan hukum kebiasaan internasional. Dalam Konvensi Wina tahun 1961 tentang hubungan diplomatik, asas resiprositas bermakna sebagai asas hukum yang melandasi pelaksanaan hak dan kewajiban negara yang diatur dalam ketentuan konvensi tersebut. Berdasarkan makna asas resiprositas yang terkandung dalam Pasal 9 Konvensi dan dengan mencermati kecenderungan yang terjadi dalam praktiknya, maka dapat ditentukan bahwa asas resiprositas dapat menjadi landasan yang legal dalam deklarasi persona non-grata terhadap pejabat diplomatik. Deklarasi persona non-grata atas dasar asas resiprositas ini merupakan suatu tindakan pembalasan yang masuk dalam kategori retorsi. Retorsi 
merupakan suatu tindakan pembalasan yang legal dan dibenarkan menurut Hukum Internasional.

Ridhowan (2014) melakukan kajian terhadap resiprositas dalam tradisi Buwuh. Hasil penelitian tersebut menunjukkan bahwa masyarakat Desa Kaliaman selalu berusaha melakukan pertukaran pemberian Buwuh secara seimbang. Proses pencatatan Buwuh dalam acara hajatan dilakukan untuk meminimalisasi adanya pertukaran pemberian Buwuh yang tidak seimbang. Pertukaran yang belum seimbang membuat orang yang belum mengembalikan Buwuh memiliki tanggungan potongan yang diartikan sebagai hutang yang harus dibayarkan. Perbedaan intensitas dalam menyelenggarakan hajatan disikapi oleh para pelaku tradisi Buwuh untuk menyelenggarakan hajatan yang dimiliki oleh masing-masing individu berdasarkan jumlah anak yang dimiliki. Hajatan terakhir yang dilakukan seseorang, digunakan warga sebagai kesempatan terakhir mengembalikan semua Buwuh yang pernah diterima dari orang tersebut. Tradisi Buwuh berperan meringankan beban seseorang yang sedang menyelenggarakan hajatan, namun di sisi lain tradisi Buwuh juga menambah kebutuhan hidup baru bagi para pelakunya, yaitu kebutuhan untuk memberikan buwuh dalam hajatan.

Setiap tradisi memiliki makna yang dipahami sebagai pedoman yang merepresentasikan tindakan atau perbuatan yang telah dan akan dilakukan, Fitria dan Rohmad (2017) mengkaji makna simbolis tradisi Burak dalam komunikasi ritual suku Bugis di Kota Bengkulu. Makna simbol tradisi Burak dalam setiap simbol, yaitu: (1) batang pisang bermakna menegakkan agama Islam; (2) batang bambu bermakna aqidah yang kuat dan lurus untuk menyembah Allah dan mencontoh sikap Rasul; (3) telur yang terdiri dari tiga bagian, yaitu cangkang telur, putih telur dan kuning telur (inti) bermakna fisik, jiwa, dan qolbu; dan (4) kertas berwarna dibentuk beraneka bunga bermakna rahmat bagi seluruh alam.
Sejauh ini, dari beberapa kajian terdahulu tersebut belum ada yang melakukan kajian tentang resiprositas pada tradisi Ngamek Ari yang dilakukan oleh masyarakat Banyuasin III. Hal tersebut menjadi salah satu alasan untuk mengkaji lebih serius tentang bentuk dan makna dalam tradisi tersebut. Di samping itu, alasan lain dari kajian resiprositas dalam tradisi Ngamek Ari tersebut adalah hasil oberservasi bahwa dalam beberapa kegiatan tradisi ini sudah mulai ditinggalkan sehingga jika tidak didokumentasi, generasi berikutnya akan kehilangan informasi dan tidak dapat mengetahui bahwa tradisi resiprositas sebagai perekat sosial masyarakat pernah hidup dalam budaya mereka.

Beberapa pendapat menyatakan bahwa resiprositas sebagai proses imbal balik, yaitu pertukaran timbal balik antarindividu atau antarkelompok (Sairin, 2002). Pertukaran imbal balik yang dimaksud adalah interaksi sosial dalam kehidupan masyarakat terutama yang terbentuk atas dasar persamaan nasib sehingga timbul keinginan untuk menolong dan sekaligus untuk meringankan beban bagi para anggotanya dalam melaksanakan suatu kegiatan yang dilandasi oleh keterikatan yang mendalam. Salim (2003) menilai bahwa sebagai sebuah pertukaran imbal balik, resiprositas bertumpu pada asumsi dasar bahwa orang bersedia melakukan pertukaran sosial karena dalam persepsi mereka kemungkinan akan mendapat penghargaan (reward). Penghargaan yang diperoleh dapat berbentuk uang, dukungan sosial (simpatisan), prioritas, penghormatan, dan kerelaan.

Marzali (2005) mengemukakan bahwa dalam pertukaran yang berdasarkan atas asas timbal balik, pada mulanya pemberian tampak dilakukan secara sukarela, tanpa pamrih, dan spontan oleh satu pihak kepada pihak yang lain. Sebenarnya, pemberian itu diberikan karena kewajiban atau dengan pamrih yang pada gilirannya akan menimbulkan kewajiban pula bagi pihak yang menerima untuk membalas di kemudian hari. Pemberian tersebut dapat dilihat sebagai bentuk pertolongan jika dilakukan 
secara individu, namun jika dilakukan secara bersama dapat dikatakan gotong royong karena pada prinsipnya terdapat perbedaan ciri antara tolong-menolong dan gotong royong. Perbedaan tersebut dapat dijelaskan pada berikut ini. masyarakat Banyuasin III, khususnya masyarakat di Desa Petaling.

\begin{tabular}{|c|c|}
\hline \multicolumn{1}{|c|}{ Gotong Royong } & tolong-menolong \\
\hline 1. kerja sama untuk menyelesaikan suatu & 1. kerja sama untuk menyelesaikan suatu \\
gawe (proyek) kepentingan bersama & gawe milik suatu keluarga individu. \\
2. tidak ada prinsip resiprocity & 2.berdasarkan atas prinsip resiprocity. \\
3. kecurangan terjadi apabila seseorang & 3. kecurangan terjadi seseorang tidak \\
tidak berpartisipasi dalam gawean & "membalas" jasa benda yang telah \\
& diterima dari pemberi. \\
\hline
\end{tabular}

Koentjaraningrat (2007) mengulas bahwa dari sisi ekonomi resiprositas berlandaskan pada prinsip transaksi ekonomi yang elementer, yakni orang menyediakan barang atau jasa dan sebagai imbalannya berharap memperoleh barang dan jasa yang diinginkan. Lebih jauh, resiprositas memiliki asumsi sederhana bahwa interaksi sosial itu mirip dengan transaksi ekonomi, tetapi tidak selalu berukuran dengan nilai uang. Hal itu disebabkan bahwa pada transaksi sosial ditukarkan juga pada hal-hal nyata.

Dari pendapat di atas dapat disimpulkan bahwa resiprositas merupakan tindakan pertukaran imbal balik, baik berbentuk barang maupun jasa karena terjadi interaksi dan komunikasi sosial. Dalam membangun interaksi dan komunikasi pada tindakan resiprositas melibatkan unsur dasar penggunaan bahasa sebagai media dalam penyampaiannya. Oleh karena itu, kemampuan memaknai setiap tindak resiprositas untuk mempermudah dalam menentukan tindakan antisipasif sebagai konsekuensi yang timbul dikemudian hari terutama pada proses imbal balik.

Atas dasar itulah kajian ini berfokus untuk mendiskusikan bentuk dan makna resiprositas dalam tradisi Ngamek Ari yang dilakukan
Kajian inimenggunakan metode deskriptif kualitatif yang bertujuan untuk menjelaskan bentuk dan makna resiprositas dalam tradisi Ngamek Ari. Sumber data pada kajian ini adalah sejumlah tokoh masyarakat yang mengetahui dan melaksanakan tradisi tersebut. Mereka berjumlah delapan orang (seimbang antara laki-laki dan perempuan) berusia di atas 40 tahun dengan mempertimbangkan keaktifan, keterlibatan, dan partisipasi mereka di tengah masyarakat. Data diperoleh dengan metode catat atau rekam dengan teknik simak libat cakap. Kemudian, data dapat dipilah dan dianalisis dengan metode padan dengan teknik pilah unsur penentu untuk mendapatkan bentuk dan makna resiprositas (Sudaryanto, 2015) yang terdapat pada tradisi Ngamek Ari.

\section{Hasil dan Pembahasan}

Ngamek Ari berasal dari kata 'mengambil' dan 'hari' yang telah mengalami perubahan bunyi akibat pelesapan unsur kata karena pengaruh dialek bahasa Melayu Musi. Ngamek Ari merupakan bentuk resiprositas, yaitu tradisi imbal-balik (sumbang/sokong/bantu) yang dilakukan masyarakat Banyuasin III, khususnya Desa Petaling sebagai solidaritas sosial sesama anggota masyarakat dalam bentuk sumbangan. 
Menyumbang adalah memberikan sesuatu kepada orang yang sedang melakukan, membutuhkan sesuatu, atau mengadakan hajatan (pesta), dan lain sebagainya sesuai dengan kemampuan penyumbang (KBBI, 2008). Hal itu dapat dimaknai bahwa penyumbang bebas batas dalam memberi sumbangan. Tindakan tersebut (oleh masyarakat Banyuasin III disebut sokongan) untuk turut serta meringankan pemilik hajatan, baik dalam bentuk tenaga, moril, atau materil. Sumbangan biasanya diberikan berdasarkan kemampuan penyumbang tanpa ada unsur yang mengikat atau memaksa. Pada intinya, orang yang menerima sumbangan tidak terikat harus mengembalikan atau membayar kembali kepada penyumbang.

Dalam kurun dua dekade terakhir terjadi pergeseran nilai dalam tradisi Ngamek Ari. Berdasarkan hasil wawancara diketahui bahwa sebelumnya Ngamek Ari dapat dikelompokkan dalam kegiatan menyumbang, yaitu kegiatan memberi bantuan atau menyokong secara sukarela kepada seseorang yang sedang atau akan mengadakan pesta tanpa mengharapkan bantuan itu akan dibalas suatu saat nanti. Namun, dewasa ini Ngamek Ari dikategorikan membantu, yaitu memberi sokongan dengan mempertimbangkan bahwa orang yang dibantu dapat membalas bantuan kelak. Pemberi bantuan (orang yang Ngamek Ari) seperti menanamkan saham kepada orang yang punya hajatan, yaitu suatu saat nanti dia akan mendapat bantuan serupa dari orang yang dibantu. Untuk mendapatkan bantuan orang lain, dia harus membantu terlebih dahulu atau Ngamek Ari. Bagi orang yang dibantu, dia harus mengembalikan bantuan tersebut pada saatnya nanti, yaitu ketika orang yang Ngamek Ari tersebut memiliki dan melaksanakan suatu pekerjaan atau hajatan.

Untuk membedakan menyumbang atau membantu dalam praktiknya, tradisi Ngamek Ari (sebelumnya) dalam bentuk sumbangan ayam, penerima sumbangan hanya mencatat jumlah (ekor) ayam yang disumbangkan tidak diperhitungkan besar dan kecil ayam yang disumbangkan. Akan tetapi, Ngamek Ari (dewasa ini) dalam bentuk membantu, penerima bantuan tidak hanya mencatat jumlah (ekor) ayam yang diterima, tetapi dia juga mencatat jumlah berat $(\mathrm{kg})$ yang diterima (hasil wawancara). Hal itu dapat dimaknai bahwa jika suatu saat penerima sumbangan mengembalikan sumbangan ketika (orang Ngamek Ari melaksanakan hajatan) dia dapat mengembalikan (mayar utang) setidaktidaknya jumlah (ekor) sama (biasanya lebih) dari yang pernah dia terima tanpa melihat besar atau kecilnya (ayam). Namun, Ngamek Ari dalam bentuk membantu, penerima bantuan harus mengembalikan jumlah berat $(\mathrm{kg})$ ayam yang pernah dia terima dan harus dikembalikan sama (biasanya lebih) dari yang pernah dia terima. Begitu pula dengan bentuk bantuan yang lain seperti dalam bentuk tenaga atau barang.

Tradisi ini tidak dapat dikatakan menyumbang karena orang yang Ngamek Ari bertujuan menanamkan pamrih dan jika dia melaksanakan hajatan bantuan yang pernah diberikan harus dia terima kembali. Tradisi ini dapat dilakukan secara individu maupun kelompok yang bertujuan untuk meringankan pekerjaan bagi orang yang dibantu. Pada pelaksanaannya, tradisi Ngamek Ari ini dapat dipahami bentuk dan maknanya.

\subsection{Bentuk dan Makna dalam Tradisi Ngamek Ari}

Ngamek Ari dilakukan sebagai tindak solidaritas sosial masyarakat Banyuasin III dapat dikelompokkan dalam tiga bentuk, yaitu tenaga, bahan atau barang, dan uang.

Adapun makna yang dimaksud dalam kajian ini adalah bagi pemberi bantuan harus memahami bahwa ketika memutuskan untuk Ngamek Ari, dia harus mempersiapkan sendiri alat yang diperlukan pada bentuk Ngamek Ari yang akan ikuti. Jika dia mendapati ada kesempatan untuk Ngamek Ari Nebang, maknanya dia harus mempersiapkan segala peralatan yang menunjang pekerjaan 
menebang, seperti membawa parang yang sesuai untuk menebang, batu asahan, dan bahkan kebutuhan pribadi, seperti rokok.

Berikut ini beberapa bentuk dan makna resiprositas dalam tradisi Ngamek Ari di Banyuasin III, khususnya di Desa Petaling di antaranya melalui Ngamek Ari dengan tenaga, Ngamek Ari dengan bahan, dan Ngamek Ari dengan uang.

\subsubsection{Tenaga}

Bentuk Ngamek Ari yang menggunakan tenaga sebagai tindak resiprositas lebih dikenal dengan istilah sambatan. Dalam Ngamek Ari berbentuk tenaga tersebut pemberi bantuan terlibat (bekerja) secara langsung pada pekerjaan yang dilaksanakan. Berdasarkan hasil analisis, tradisi Ngamek Ari tersebut banyak dilakukan dalam kegiatan pertanian, seperti kegiatan beume atau berhuma (berladang). Kegiatan beume tersebut dapat diuraikan sebagai berikut.

\section{Nebas atau menebas}

Nebas atau tebas adalah kegiatan membuka lahan baru untuk beume. Tebas atau menebas menurut KBBI (2008) adalah memotong (merambah) tumbuhan yang kecilkecil. Jika seseorang ingin membuka lahan baru, dia harus membersihkan dengan cara menebas.

Seseorang yang ingin Ngamek Ari Nebas diharuskan menyiapkan alat khusus untuk memotong tumbuhan yang kecil. Nebas dapat dimaknai bahwa dia harus membawa parang, yaitu parang penebas. Bentuk Ngamek Ari tersebut dapat melibatkan laki-laki dan perempuan. Resiprositas yang akan dilakukan oleh pemilik gawean/gewean adalah jumlah hari atau sore hari atau petang dia dibantu.

\section{Nebang atau menebang}

Setelah lahan dibersihkan atau ditebas, kegiatan berikutnya adalah nebang. Nebang atau tebang adalah memotong (pokok, batang) pohon, biasanya yang lebih besar (KBBI, 2008). Jika nebas adalah membersikan semak belukar, maka nebang atau tebang adalah memotong pohon (pohon karet). Seseorang yang ingin Ngamek Ari Nebang harus menyiapkan peralatan, seperti parang yang harus dibawa adalah parang mundok. Ngamek Ari Nebang biasanya hanya dilakukan oleh laki-laki. Resiprositas yang akan dilakukan oleh pemilik gawean adalah menghitung jumlah hari atau sore orang yang telah membantunya menebang.

\section{Tutoh atau metutuh}

Setelah pohon ditebang, kegiatan berikutnya adalah tutoh atau menutoh. Menutoh adalah memotong dahan kayu yang sudah ditebang. Kemudian, potongan dahan disebarkan secara merata untuk menutupi permukaan tanah. Mereka yang Ngamek Ari akan membawa perlengkapan menutoh, seperti parang (penebasan dan mundok) dan batu asahan untuk mempertajam mata parang.

\section{Makar atau membakar}

Makar atau membakar dapat dilaksanakan jika pohon dan dahan telah ditutoh, disebar, dan kering dengan sempurna. Mereka yang Ngamek Ari Makar akan membawa beberapa perlengkapan seperti colop dan ember. Makar biasanya dilaksanakan di atas pukul 15.00 yang diikuti oleh laki-laki dan perempuan. Mereka yang ikut Ngamek Ari adalah mereka yang berencana membuka lahan dan jika makar nanti berharap akan dibantu pula. Dalam kurun satu minggu setelah pembakaran dilanjutkan merun, yaitu kegiatan membersihkan sisa pembakaran. Mereka yang Ngamek Ari akan membawa perlengkapan seperti parang berukuran kecil untuk memotong ranting sisa pembakaran kemudian dikumpulkan atau diperun-kan sehingga membentuk onggokan kecil atau perunan dan dibakar kembali. Pohon atau kayu yang tidak terbakar ditepikan pada bagian sisi lahan atau ladang dan digunakan untuk membuat pagar atau kandang. Pemilik lahan akan mayar utang atau membayar utang berdasarkan berapa hari atau berapa sore dia mendapat bantuan. 


\section{Ngandang atau mengandang}

Ngandang atau mengandang adalah membuat kandang atau pagar oleh pemilik ladang atau lahan untuk melindungi tanaman dari binatang liar seperti babi hutan, sapi, atau kambing yang dilepasliarkan oleh pemiliknya. Mereka yang Ngamek Ari akan menyiapkan tenaga guna mengangkat kayu untuk mator (membuat landasan untuk kandang) atau menegakkan turus yang sudah diruncingkan untuk menyusun kayu. Pemilik lahan akan mayar utang berdasarkan berapa hari atau berapa sore dia dibantu.

\section{Nugal atau menugal}

Nugal merupakan salah satu kegiatan Ngamek Ari yang harus dibayar oleh pemilik lahan atau pemilik ume jika suatu saat memiliki pekerjaan yang sama. Mereka yang ikut Ngamek Ari Nugal terdiri atas laki-laki dan perempuan. Ketika Ngamek Ari Nugal, lakilaki biasanya membawa membawa parang untuk mengambil kayu sepanjang 2-3 meter untuk dibuat tugal. Kayu tersebut dibuat runcing (pancut domok) untuk membuat langsak (lubang kecil) untuk menempatkan benih yang akan ditanam. Langsak berguna untuk menempatkan benih untuk mencegah benih terbawa air jika hari hujan. Bagi perempuan, mereka membawa tempat menampung benih, seperti mangkuk, ember kecil, dan lain sebagainya. Mereka akan meneh yaitu, memasukkan benih ke dalam langsak.

\section{Merencam, betanjar, dan betandur}

Merencam merupakan kegiatan menyemai benih pada tempat kering (tidak tergenang air) sebelum padi dibawa ke sawah. Setelah tumbuh setinggi $10-15 \mathrm{~cm}$, benih dipindahkan ke sawah atau tempat yang dekat dengan sawah di atas tanah yang lembab atau tergenang air yang disebut tanjaran. Benih ditanam kembali (betanjar) hingga tumbuh setinggi $30-40 \mathrm{~cm}$. Pada kegiatan ini tradisi Ngamek Ari belum dilakukan. Setelah ketinggian pada sudah dirasa cukup, pemilik sawah biasanya akan memindahkan padi ke sawah dan ditanam satu atau dua batang pada setiap rumpun tanam (betandur). Mereka yang Ngamek Ari biasanya akan membawa alat untuk betandur yang disebut tunjam. Pekerjaan ini dapat dilakukan oleh laki-laki dan perempuan. Pemilik sawah wajib membayar balik (resiprositas) bantuan yang diberikan dengan menghitung jumlah hari atau jumlah luas padi yang sudah ditanam dalam hitungan julat. Julat adalah hitungan luas sawah secara tradisional dengan ukuran $20 \times 20 \mathrm{~m}^{2}$.

\section{Menyesap atau merumput}

Menyesap atau merumput dapat pula digolongkan sebagai pekerjaan yang dikategorikan melibatkan sejumlah orang dalam tradisi Ngamek Ari. Mereka yang mau Ngamek Ari seperti merumput atau menyesap biasanya akan membawa alat seperti tajak atau parang lendung. Merumput merupakan tindakan membersihkan lahan dari rumput liar atau gulma yang dapat menghambat tumbuh kembang tanaman lain. Menyesap adalah pekerjaan untuk membersihkan batang padi yang sudah dipanen karena jika tidak dibersihkan, maka batang padi itu akan tumbuh menjadi padi baru yang tidak dapat berbuah sehingga membuat tanaman yang ada di sekitarnya menjadi kerdil (kerit). Batang padi yang sudah dibersihkan (sesap) akan disebarkan secara merata sebagai pupuk kompos untuk menyuburkan tanah. Pemilik lahan atau pemilik ume akan melakukan resiprositas (mayar balik) dengan menghitung jumlah hari dia dibantu seseorang atau sekelompok orang. Sekelompok orang pada kajian ini dapat dimaknai jika yang membantu lebih dari satu orang memiliki hubungan keluarga, seperti ibu dan anak atau saudara.

\section{Ngetam ata mengetam (panen)}

Ngetam atau panen merupakan kegiatan mengambil padi di sawah atau ladang. Pekerjaan ini dapat dilakukan oleh laki-laki atau perempuan. Mereka yang Ngamek Ari akan membawa perlengkapan memanen padi, seperti alat pomotong tangkai padi (tuai), alat untuk 
menampung padi sementara, seperti kidding (ketiding) atau brunang, dan alat penampung untuk membawa padi yang sudah dipanen, seperti purun atau karung. Ngamek Ari Ngetam hanya dapat dilakukan jika terjadi panen raya, baik di ladang maupun di sawah. Hal itu karena jika tidak melakukan tradisi Ngamek Ari dikhawatirkan padi tidak akan dapat dipanen seluruhnya dalam kondisi yang sempurna. Hal itu akan berakibat padi menjadi hangus atau motong.

Pada panen raya selain Ngamek Ari juga dikenal istilah pelarian, yaitu kegiatan saling bantu antarpetani atau gotong royong. Pelarian ini dapat juga dilakukan pada pekerjaan lain, di antaranya panen raya hasil ladang atau sawah, para petani akan berbagi hari, misalnya satu hari panen di sawah si A, hari berikutnya di sawah si B, dan seterusnya. Kegiatan ini hanya dapat dilakukan dalam kondisi darurat yang disebabkan oleh cuaca, seperti hujan, panas, atau kondisi tanaman siap panen yang jika dipanen oleh orang (sedikit jumlahnya) dikhawatirkan tanaman itu cepat hangus (motong) atau busuk. Oleh karena itu, petani bekerja secara gotong royong (pelarian) agar memanen dilakukan secara bersamaan sehingga cepat selesai dan mendapatkan hasil yang memuaskan.

Pemilik sawah mempunyai beberapa alternatif dalam kegiatan Ngamek Ari tersebut. Pertama, jika mereka yang Ngamek Ari berbagi hasil panen yang didapatkannya dengan pemilik sawah, maka gugurlah resiprositas atau kewajiban membayar balik kepada mereka. Namun, jika mereka yang Ngamek Ari tidak mau berbagi hasil (hasil diserahkan semua kepada pemilik sawah), pemilik sawah atau ladang wajib membayar balik sebanyak jumlah hari bantuan yang dia peroleh. Alternatif kedua hanya berlaku jika mereka yang Ngamek Ari juga memiliki sawah atau ladang yang siap untuk dipanen.

\subsubsection{Bahan, Barang, dan Uang}

Selain bentuk tenaga, resiprositas dalam tradisi Ngamek Ari juga ditemukan dalam bentuk bahan, barang, atau uang. Resiprositas bentuk bahan atau barang tersebut dapat digolongkan dalam dua jenis kegiatan, yaitu membangun rumah dan hajatan.

\section{Bahan Bangunan}

Membangun rumah adalah suatu pekerjaan yang membutuhkan banyak tenaga dan bahan. Untuk meringankan beban tersebut, banyak yang ingin Ngamek Ari dengan membantu bahan bangunan. Sebelumnya, bantuan yang diberikan mayoritas berbentuk tenaga. Namun, seiring dibutuhkan keahlian khusus untuk mendirikan sebuah rumah, maka banyak yang hanya membantu bahan. Bentuk bantuan bahan atau material bangunan yang diberikan dapat berbeda dari setiap orang yang ingin Ngamek Ari tersebut. Material bangunan yang digunakan untuk membangun rumah dapat diberikan berupa bantuan semen, genteng, kayu (ramonan), pasir, besi, dan lain-lain.

Penerima bantuan harus mengembalikan (mayar utang) berbentuk semen harus mengembalikan dengan menghitung jumlah sak semen yang diterima. Begitu pun pengembalian jenis bantuan bahan lain, seperti genteng, kayu, pasir, dan besi dengan menghitung jumlah ukuran dari setiap material yang diterima. Biasanya, tradisi Ngamek Ari ini dilakukan bagi mereka yang memiliki rencana untuk membangun rumah sehingga ketika mereka membangun dan membutuhkan bahan-bahan tersebut, dia cukup mengabari orang yang pernah dibantu.

\section{Kebutuhan pokok}

Mereka yang melakanakan hajatan perlu merencanakan dan melakukan persiapan yang matang. Mereka harus memperkirakan atau mengidentifikasi barang-barang yang dibutuhkan untuk melaksanakan hajatan. Mereka yang ingin Ngamek Ari biasanya memanfaatkan kondisi ini untuk membantu sekaligus menabung barang. Dalam tradisi Ngamek Ari barang yang dapat digunakan untuk biasanya berkaitan dengan bahan pokok untuk dikonsumsi, seperti buah kelapa, tepung, 
gula, minyak goreng, ayam, daging, beras, dan lain sebagainya.

Pemilik hajatan biasanya akan menugaskan seseorang untuk mencatat orang yang Ngamek Ari dan bantuan yang diberikan. Hal tersebut berguna untuk menghindari kesalahan atau kekeliruan dalam pengembaliannya (mayarutang) nanti. Bantuan biasanya diberikan dalam dua kegiatan, pertama orang yang Ngamek Ari dapat secara pribadi dan memberi bantuan untuk Ngamek Ari. Barang yang diberikan biasanya dalam jumlah yang agak besar, misal Ngamek Ari dengan ayam sebanyak limapuluh kilogram (50kg). Kedua, Ngamek Ari secara umum, mereka yang memberikan bantuan datang bersamasama, yang dikenal dengan istilah tewean. Barang yang diberikan dapat berupa $1 \mathrm{~kg}$ minyak goreng, dua butir kelapa, dua ekor ayam, dan lain sebagainya untuk setiap orang (biasanya ibu-ibu rumah tangga). Barangbarang itu ditaruh dalam mangkuk (jamangan) berukuran sedang dan dibalut dengan kain ukuran satu meter persegi, seperti kain taplak meja, lalu diantarkan secara bersama-sama ke tempat hajatan.

\section{Uang}

Lelang berbentuk uang merupakan resiprositas pada tradisi Ngamek Ari yang dilakukan oleh masyarakat Banyuasin, khususnya di Desa Petaling. Resiprositas ini biasanya dilakukan pada saat pesta hajatan berlangsung yang diiringi oleh orkesan (kelompok musik). Pada tradisi Ngamek Ari tersebut, pemilik hajatan menunjuk beberapa orang untuk mencatat jumlah bantuan yang diberikan oleh setiap individu. Ngamek Ari tersebut sebagai ajang untuk memperlihatkan tingkat kemampuan ekonomi seseorang. Pemilik hajatan menyediakan ayam sebagai tanda terima yang diberikan kepada orang yang Ngamek Ari. Peminat Ngamek Ari mendaftar kepada panitia yang telah ditunjuk serta menyebutkan besar lelang yang diberikan. Kemudian, panitia mengurutkan nominal lelang mulai dari urut yang tinggi. Setelah itu, panitia memanggil nama peserta lelang yang tertinggi dan menyebutkan besarnya jumlah nominal yang diberikan ke atas pentas. Kemudian, mereka diberi tanda terima lelang berupa seekor ayam bakar dan diberi kesempatan untuk menyanyikan sebuah lagu dengan diringi oleh orkes. Kepopularan grup musik yang disewa pemilik hajatan ikutmenentukan dan menaikkan nilai bantuan atau lelang Ngamek Ari.

\subsubsection{Mayar Utang}

Pada tradisi Ngamek Ari, mayar utang (membayar utang) merupakan pengembalian bantuan yang diterima oleh pemilik hajatan. Penerima bantuan harus mengembalikan bantuan yang dia terima. Pengembalian bantuan seharusnya sama dengan nilai atau jumlah bantuan yang diberikan, tetapi pada kenyataannya penerima bantuan biasanya melebihkan pengembalian (ngiring) sebagai wujud terima kasih. Jika tidak dilebihkan, mereka dipandang atau dianggap tidak tahu terima kasih. Akan tetapi, jika mereka tidak bisa mengiringi mereka dapat berbicara langsung kepada pemberi bantuan untuk memberitahukan alasannya. Namun, jika mereka tidak memberitahukan alasannya, mereka akan menerima konsekuensi, yaitu jika dia mengadakan hajatan lagi, orang tidak akan ikut Ngamek Ari, bahkan tidak ada orang yang datang untuk memenuhi undangannya.

Di sisi lain, jika penerima bantuan tidak mayar utang, pemberi bantuan dapat menagih atau meminta bantuannya dibayar. Hal tersebut jarang terjadi karena tradisi Ngamek Ari merupakan kegiatan sosial yang bertujuan untuk meringankan beban pemilik hajatan sehingga jika tiba waktunya, penerima bantuan akan berusaha mayar utang atas bantuan yang pernah dia terima.

\subsection{Pembahasan}

Dari hasil yang diuraikan di atas, Ngamek Ari merupakan bantuan imbal balik yang bertujuan untuk meringankan pemilik hajatan. Bantuan yang diberikan terdiri atas beberapa bentuk, seperti, bantuan tenaga, bahan dan 
barang, dan uang. Setiap bentuk bantuan dalam tradisi Ngamek Ari dapat dilakukan hanya pada pekerjaan tertentu. Ngamek Ari dalam bentuk bantuan tenaga tidak dapat disamakan dengan Ngamek Ari bentuk bantuan bahan atau barang, begitu pula sebaliknya. Pembahasan bentuk dan makna Ngamek Ari sebagai berikut.

Bantuan dalam Ngamek Ari berbentuk tenaga banyak dilakukan pada pekerjaan membuka lahan atau berladang dan bersawah. Dalam pelaksanaan tradisi Ngamek Ari tenaga, bentuk bantuan yang diberikan tergantung jenis pekerjaan, misalnya nebas, orang yang Ngamek Ari sudah mengetahui bahwa dia harus mempersiapkan peralatan tertentu seperti, parang penebasa agar dapat memberikan bantuan dengan lancar. Artinya, jika dia tidak membawa peralatan sendiri, dia tidak bisa bekerja sehingga dia tidak akan mendapat imbal balik. Pada Ngamek Ari Nebang, orang yang Ngamek Ari harus menyiapkan peralatan untuk menebang, seperti parang mundok. Hal demikian berlaku pula pada Ngamek Ari Nugal, yaitu mereka harus membawa kayu sebagai alat untuk menugal yang sudah dibuat runcing atau dipancut domok agar lubang (langsak) yang dihasilkan lebar sehingga mudah memasukkan benih (beneh) ke dalamnya, seperti biji padi, jagung, kacang, dan lain sebagainya.

Dewasa ini tradisi Ngamek Ari berbentuk bantuan tenaga sudah mulai ditinggalkan karena pemilik gawean cenderung menempuh cara yang mudah, praktis, dan ekonomis, yaitu dengan menjual secara borongan (morongke). Contoh, untuk membuka lahan yang masih terdapat banyak pohon, seperti karet, pemilik lahan dapat menjual (morongke) pohon yang terdapat di atas lahan kepada orang lain. Untuk mengambil pohon yang akan ditebang, pemborong harus memotong atau menebas tumbuhan kecil yang ada di sekitar pohon dan secara tidak langsung pemilik lahan tidak perlu menebas lahannya karena sudah dikerjakan oleh pemborong. Di samping itu, program pemerintah untuk meningkatkan produksi getah karet (lateks) mendorong perubahan pada peremajaan perkebunan karet rakyat dari penggunaan bibit karet hutan kepada bibit hasil okulasi. Kemudian, larangan pemerintah membuka ladang melalui cara membakar berdampak pada hilangnya beberapa bentuk tradisi Ngamek Ari, seperti nebas, nebang, nutoh, makar, dan merun karena pemilik lahan cenderung mengupahkan pekerjaan tersebut.

Pada tradisi Ngamek Ari barang dan uang, pemilik hajatan atau pemilik gawean tidak bisa mengalihkan bentuk barang kepada bentuk lain, kecuali atas kesepakatan bersama. Hal itu dapat terjadi karena suatu kondisi, seperti pemilik gawean menerima bantuan semen, namun karena sesuatu dan lain hal dia minta diganti dengan batu bata, maka semen dapat diganti dengan batu bata dengan harga setara. Lain halnya dengan uang, pada tradisi Ngamek Ari uang (seperti lelang), pemilik hajatan (gawean) dapat membayar kembali setara bantuan yang telah diterima. Artinya, ketika mayar utang, pemilik hajatan dapat membayar atau mengembalikan dengan jumlah yang sama atau lebih. Jika dia hanya membayar sesuai dengan bantuan, maka hutangnya dianggap selesai. Namun, jika dia membayar lebih (ngiring), kelebihan itu akan dicatat sebagai bantuan yang wajib dibayar kembali ketika dia melaksanakan hajatan berikutnya.

Mereka Ngamek Ari uang biasanya terjadi pada hajatan (pesta) pernikahan yang dikenal dengan acara lelang. Peserta lelang adalah para undangan yang hadir atau diwakilkan mengikuti kegiatan itu. Mereka dapat dibedakan dalam dua kategori, Ngamek Ari dan Mayar Utang. Ngamek Ari adalah para undangan yang mengikuti lelang dan memberi uang sebagai bantuan, maka pemilik hajatan wajib membayar balik pada suatu ketika. Mayar utang adalah mereka yang pernah dibantu oleh pemilik hajatan dan ketika itu mereka mengembalikannya. Pada kategori ini, peserta lelang yang mayar utang mengembalikan setara denganjumlah lelang dia terima, dengan kata lain mereka tidak membayar lebih (tidak ngiring), maka pemilik 
hajatan tidak ada kewajiban membayar kembali. Kondisi tersebut dapat terjadi karena orang yang mayar utang tidak mempunyai keluarga atau anak jadi dia tidak mungkin melaksanakan hajatan yang serupa di kemudian hari.

Bagi peserta lelang yang membayar lebih (ngiring) dari yang semestinya, pemilik hajatan berkewajiban membayar kelebihan tersebut jika yang Ngamek Ari melaksanakan hajatan serupa. Sebagai ilustrasi berikut ini dijelaskan mayar utang dengan ngiring. Contoh, A mengikuti lelang dan Ngamek Ari sebanyak limaratus ribu rupiah (Rp500.000,00) kepada B. Kemudian, A melakanakan hajatan dan B mayar utang dengan jumlah tujuhratus ribu rupiah (Rp700.000,00). B mengembalikan uang, mayar utang, limaratus ribu rupuah (Rp500.000,00) dan ngiring sebanyak duaratus rupiah $(\mathrm{Rp} 200.000,00)$, maka B Ngamek Ari kembali sebanyak Rp200.000,00, dan si A wajib mayar utang pada suatu saat nanti.

\section{Simpulan}

Dari pembahasan di atas dapat disimpulkan bahwa tradisi Ngamek Ari bertujuan untuk membantu meringankan beban pemilik hajatan (pekerjaan). Untuk meringankan beban tersebut terdapat beberapa bentuk Ngamek Ari yang dilakukan oleh masyarakat Banyuasin III, terutama masyarakat Desa Petaling. Pertama, tenaga, yaitu Ngamek Ari membantu dengan tenaga untuk membantu untuk meringankan pemilik gawean. Kedua, bahan atau barang, yaitu Ngamek Ari yang diberikan dalam wujud bahan atau barang, seperti semen, pasir, batu bata, dan lain-lain. Bantuan tersebut biasanya diberikan untuk membangun rumah. Ketiga, uang, yaitu Ngamek Ari memberi bantuan untuk meringankan pemilik hajatan berupa uang, seperti lelang pada hajatan pernikahan. Pemilik hajatan atau pekerjaan yang menerima bantuan wajib mayar utang atau mengembalikan bantuan yang dia terima minimal sama jumlahnya atau dilebihkan (ngiring). Nilai dasar dari tradisi tersebut adalah nilai tolongmenolong untuk membantu meringankan beban pemilik hajatan atau gawean dalam melaksanakan hajatan atau pekerjaan. Tradisi ini perlu dilestarikan. Oleh karena itu, pengambil kebijakan dan pemangku kepentingan perlu merevitalisasi dan merumuskan kembali nilai dasar yang terkandung pada tradisi tersebut.

\section{Daftar Pustaka}

Block, Fred and Magaret Somers. 2014. The Power of Market Fundamentalism: Karl Polanyi's Critique. Harvar: Harvard University Press.

Esten, Mursal. 1999. Kajian Transformasi Budaya. Bandung: Angkasa.

Engelmann, D., \& Fischbacher, U. (2009). 'Indirect Reciprocity and Strategic Reputation Building in an Experimental Helping Game.' Games and Economic Behavior, 67, 399-407. http://doi.org/ 10.1016/j.geb.2008. 12.006 (diakses, 6 Februari 2017).

Fitria, Rini dan Rahmad Fadli. 2017. "Makna Simbol Tradisi Burak dalam Komunikasi Ritual Suku Bugis di Kota Bengkulu." Alhikmah. Volume 11 Nomor 1. Hal 104-117.

Gauldner, Alvin W. 1960. 'The Norm of Reciprocity: a Preliminary Statement.' American Sociological Review. Volume 25, nomor 2. Hal 161-178. (diakses, 15 Januari 2018).

Koentjaraningrat. 2007. Sejarah Teori Antropologi I. Jakarta: UI Press.

Marzali, Amri. 2005. Antropologi dan Pembangunan Indonesia. Jakarta: Prenada Media.

Mauss, Marcell. 1992. Pemberian, Bentuk, dan Fungsi Pertukaran di Masyarakat Kuno. (Terjemahan Parsudi Suparlan). Jakarta: Yayasan Obor Indonesia.

Pujileksono, Sugeng. 2009. Pengantar Antropologi. Malang: UMM Press. 
Pribadhi, Prita Ayu. 2011. "Resiprositas dalam Kehidupan Sosial Ekonomi Masyarakat: Studi Kasus pada Masyarakat Kelurahan Kauman Kabupaten Blora" (Skripsi). Semarang: Univeritas Negeri Semarang. Ridhowan, Basid (2014). "Resiprositas dalam Tradisi Buwuh: Studi Kasus di Desa Kaliaman, Kecamatan Kembang, Kabupaten Jepara” (Skripsi), Fakultas Ilmu Sosial. Yogyakarta: Universitas Negeri Yogyakarta.

Stanca, L. (2009). Measuring Indirect Reciprocity: Whose Back do We Scratch? Journal of Economic Psychology, 30, 190-202. http://doi.org/10.1016/j.joep. 2008.07.010.

Ula, Afifah Padhil, dan Hilarius S Taryanto. 2014. "Perubahan Bentuk Resiprositas
Kehidupan Sosial Masyarakat Desa Nunuk, Indramayu" (Skripsi). Jakarta: Universitas Indonesia.

Sairin, Sjafri dkk. 2002. Pengantar Sosiologi Ekonomi. Yogyakarta: Pustaka Pelajar.

Salim, Agus. 2003. Teori Sosiologi Klasik dan Modern. Sketsa Pemikiran Awal. Semarang: Unnes Press.

Sobur, Alex, 2003, Semiotika Komunikasi, Bandung: Remaja Rosdakarya.

Wawancara dengan pemuka masyarakat dan pelaku resiprositas; M.Zakaria (80 tahun), Solehan (77 tahun), Astina dan Rohana (59 dan 56 tahun), Hamsani (57 tahun), Eli Azhar (42 tahun), dan Romlah dan Aminatun (68 dan 49 tahun), Petaling, 21-30 Juni 2017. 